\title{
World No Tobacco Day reminds us of the desolating effects of smoking on health
}

\section{the tobacco \\ epidemic \\ contains \\ stories of \\ success even \\ though set \\ against a \\ dismal global \\ backdrop}

n 2004 at Columbia University in New York, I worked with colleagues assessing the economic effects of heart disease in developing economies. I was invited to Washington, DC to address young economists from the International Monetary Fund (IMF) about tobacco as a contributor to vascular disease in sub-Saharan Africa and South America.

In DC, I was not among friends. Six young men in suits armed with data generated by mathematical models of intimidating complexity told me that tobacco was good for the [economic] health of evolving economies. It was easily grown; there was always a market; and governments loved it as a stable source of tax. Health consequences did not feature in their models - and so our meeting, though courteous, was brief.

Fast forward to Melbourne, August 2010, and the 63rd United Nations-auspiced international conference of non-government organisations (NGOs) working in developing economies on health and welfare. The theme was "Advance global health: achieve the millennium development goals".

Despite the theme being like a slogan from the Chinese cultural revolution, the discussions were lively, open and constructive. Development was discussed from social, financial and political angles; but when tobacco was mentioned, quietness descended. Most representatives of the NGOs would say nothing bad about tobacco, because they had come to depend on tobacco companies' largesse as governments, strapped by the global financial crisis, struggled for air.

\section{We must resist fatigue and build on success}

Tobacco is talked about so much that there is a serious risk of complacency, despite current estimates that one billion people will die from tobacco-related diseases this century. ${ }^{1}$ Many will die of cardiovascular disease, and in the developing world one-third of these will be people aged less than 65 years. $^{2}$

But the tobacco epidemic contains stories of success even though set against a dismal global backdrop. World Bank modelling has shown that wherever tobacco is taxed, consumption falls, government revenue increases and tobacco farming can be changed to cultivate food. ${ }^{3}$ The World Bank model applies whatever the national income; raising taxes has worked in low- and middle-income countries such as South Africa, Egypt and Turkey. ${ }^{4}$

\section{We must sustain the international response}

The World Health Organization's first international treaty has been the most successful international response to the global epidemic of tobacco-related diseases. ${ }^{5}$ As the culmination of about 50 years of policy work in relation to tobacco, the Framework Convention for Tobacco Control (FCTC) ${ }^{6}$ came into force in 2005 with 168 signatory countries. It was supported by many agencies including the IMF (yes), World Bank, UNICEF, several pharmaceutical companies and international health NGOs. ${ }^{7}$ The 2011 high-level United Nations summit on noncommunicable diseases resulted in a specific commitment to reduce tobacco use through accelerated implementation of the FCTC. ${ }^{8}$ Now, 180 nations representing $89.4 \%$ of the world's population are parties to the treaty. ${ }^{9}$

The FCTC has two arms. The first comprises demandside controls covering pricing and taxation, and nonprice tactics to protect people from others' smoke and to regulate packaging and labelling, advertising and sponsorship. Supply-side measures — the second arm - are especially difficult to enact. Derek Yach, a principal contributor to the development of the treaty, writes on its tenth anniversary that

state monopolies led from China, Indonesia and India are poised to soon be the dominant manufacturers by volume of traditional tobacco products. Implementation of the FCTC will be tougher as state monopolies' power grows - as it is in the very countries where prevalence remains extremely high or increasing. ${ }^{\text {? }}$

\section{We must not rest on our laurels}

Australia ranks highly in the success of its tobacco control strategies. The prevalence of smoking in Australia has fallen from $72 \%$ in men in $1945^{10}$ to $15 \%$ now. ${ }^{11}$ The residual risks of smoking from years ago, together with those accruing to current smokers, mean there are about 15000 tobacco-associated deaths a year in Australia. ${ }^{12}$ Plain packaging is having an effect, and social mores have changed.

From here, ensuring the availability of high-quality information about tobacco and smoking through social media to assist young people to make informed choices makes good sense. New products such as e-cigarettes should be viewed with scepticism, especially given the tobacco companies' enthusiasm for them. Waterpipe smoking, for example, is enjoying a vogue in Australia ${ }^{13}$ and its health effects have been documented by the WHO. ${ }^{14}$ Support for smokers who wish to quit may not need to be extensive to be effective.

This is not an unwinnable battle.

Stephen Leeder

Menzies Centre for Health Policy, Sydney, NSW. stephen.leeder@sydney.edu.au doi: 10.5694/mjal5.c0518

References are available online at www.mia.com.au. 
1 Giovino GA, Mirza SA, Samet JM, et al; GATS Collaborative Group. Tobacco use in 3 billion individuals from 16 countries: an analysis of nationally representative cross-sectional household surveys. Lancet 2012; 380: 668-679. http:// www.thelancet.com/journals/lancet/article/PIISO1406736(12)61085-X/fulltext (accessed May 2015).

2 Harikrishnan S, Leeder S, Huffman M, et al. A race against time: the challenge of cardiovascular diseases in developing economies. New Delhi: Centre for Chronic Disease Control, 2014. http://www.ccdcindia.org/A-RACE-AGAINST-TIME.pdf (accessed May 2015).

3 World Bank. Curbing the epidemic - governments and the economics of tobacco control. Development in practice. Washington, DC; World Bank, 1999. http://documents. worldbank.org/curated/en/1999/05/437174/curbingepidemic-governments-economics-tobacco-control (accessed May 2015).

4 International Union Against Tuberculosis and Lung Disease. World Conference on Tobacco or Health 2015 Press Kit Factsheet l: Tobacco taxation. http://www.wctoh.org/media/ wctoh-2015-press-kit/document/FSI-Tobacco-Taxation-2015. pdf (accessed May 2015).

5 Yach D. The origins, development, effects, and future of the WHO Framework Convention on Tobacco Control: a personal perspective. Lancet 2014; 383: 1771-1779.

6 WHO Framework Convention on Tobacco Control (adopted by the Conference of the Parties to the WHO FCTC). Geneva: WHO, 2003. http://www.who.int/fctc/text_download/en (accessed May 2015).

7 Yach D. The WHO FCTC at 10: progress has been mixed. Framework Convention Alliance. http://www.fctc.org/fcanews/opinion-pieces/1283-derek-yach (accessed May 2015).
8 Framework Convention Alliance. UN NCD summit outcomes: notes for tobacco control advocates. http://www.fctc.org/ images/stories/NCD_Summit_Outcomes.pdf (accessed May 2015).

9 Framework Convention Alliance. Status of the WHO framework convention on tobacco control (FCTC). Updated 18 March 2015. http://www.fctc.org/images/stories/docs/ ratifications/latest_ratifications.pdf (accessed May 2015).

10 Winstanley MH, White V (updated by Germain D, Zacher M). Trends in the prevalence of smoking. In: Scollo MM, Winstanley $\mathrm{MH}$. Tobacco in Australia: facts and issues. 4th ed. Melbourne: Cancer Council Victoria, 2012. http://www.tobaccoinaustralia. org.au/downloads/chapters/Chl_Prevalence.pdf (accessed May 2015).

1 Australian Institute of Health and Welfare. National Drug Strategy Household Survey. 2013 data and references: supplementary tables. Table 2. http://www.aihw.gov.au/ alcohol-and-other-drugs/ndshs/2013/data-and-references (accessed May 2015).

12 Begg S, Vos T, Barker B, et al. The burden of disease and injury in Australia 2003. Canberra: Australian Institute of Health and Welfare, 2007. (AlHW Cat. No. PHE 82.) http://www.aihw.gov. au/WorkArea/DownloadAsset.aspx?id=6442459747

13 Wang LW, He EYJ, Ghosh D, et al. Severe carbon monoxide poisoning from waterpipe smoking: a public health concern. Med J Aust 2015; 8: 446-447.

14 World Health Organization Study Group on Tobacco Regulation (TobReg). Waterpipe tobacco smoking: health effects, research needs, and recommended actions by regulators [advisory note]. Geneva: WHO, 2005. http://www. who.int/tobacco/global_interaction/tobreg/Waterpipe\%20 recommendation_Final.pdf (accessed May 2015) 